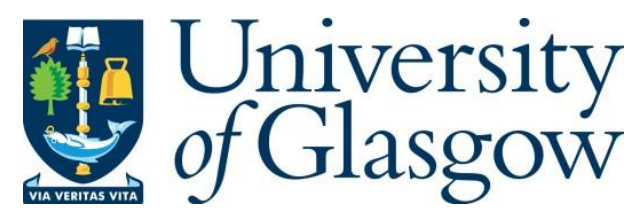

Robbie, J. (2021) Babes in the woods: the decision of the Scottish Ministers on the application of Helensburgh Community Woodlands Group to exercise the right to buy abandoned, neglected or detrimental land. Edinburgh Law Review, (Accepted for Publication).

There may be differences between this version and the published version. You are advised to consult the publisher's version if you wish to cite from it.

http://eprints.gla.ac.uk/244345/

Deposited on: 18 June 2021

Enlighten - Research publications by members of the University of Glasgow http://eprints.gla.ac.uk 


\section{Babes in the woods: the decision of the Scottish Ministers on the application of Helensburgh Community Woodlands Group to exercise the right to buy abandoned, neglected or detrimental land}

There has been woodland on this site for at least 160 years. The development plan that we will implement will result in a balanced native woodland ecosystem that will provide biodiversity, natural habitat and a peaceful green space for local residents and visitors to enjoy long into the future. ${ }^{1}$

So stated Helensburgh Community Woodlands Group ("HCWG") in their application to exercise the right to buy abandoned, neglected or detrimental land. The plot in question was situated in a residential area, designated as an Open Space Protection Area $^{2}$ and was covered by a Tree Preservation Order. ${ }^{3}$ The current owners have owned the land since 2004 and had sought successive planning permissions from the Local Authority to build housing on the land, but these had been unsuccessful. HCWG hoped to exercise the right to buy to create a community woodland. The Scottish Ministers rejected their application on four different grounds. ${ }^{4}$

Part 3A of the Land Reform (Scotland) Act 2003, which contains the provisions for the right to buy abandoned, neglected or detrimental land, came into force on 27 June $2018 .{ }^{5}$ At the time of writing, there have only been three applications under this right to buy, two of which

\footnotetext{
${ }^{1}$ Application by Helensburgh Community Woodlands Group for Consent to Exercise Right to Buy Land at South of Cumberland Avenue, Helensburgh, G84 8QP (9 December 2019) AB00001, Response to Question 8.2, Appendix 32 ("Helensburgh Application").

2 This designation is contained in the Argyll and Bute Local Development Plan 2015.

${ }^{3}$ Tree Preservation Order No.16/04 by Argyll and Bute Council, registered 26 April 2005. Planning authorities have the power to make tree preservation orders under s 160 of the Town and Country Planning (Scotland) Act 1997.

${ }^{4}$ Decision on the Application by Helensburgh Community Woodlands Group for Consent to Exercise Right to Buy Land at South of Cumberland Avenue, Helensburgh, G84 8QP (18 August 2020) AB00001 ("Helensburgh Decision").

${ }^{5}$ Land Reform (Scotland) Act 2003 part 3A. On the various community rights to buy generally, see M M Combe, "Legislating for Community Land Rights" and J A Lovett, "Towards Sustainable Community Ownership: A Comparative Assessment of Scotland's New Compulsory Community Right to Buy" both in M M Combe, J Glass and A Tindley (eds), Land Reform in Scotland: History, Law and Policy (2020) and J Robbie, "Community Rights to Buy" in W M Gordon and S Wortley, Scottish Land Law $3^{\text {rd }}$ edn vol II, edited by K G C Reid (2020) ch 31.
} 
have been rejected and one declined. ${ }^{6}$ This note will analyse the decision of the Scottish Ministers to reject the application by HCWG. HCWG were babes in the woods as they were the first community body to try to negotiate this difficult legislative terrain. The decision gives some early indications of the Scottish Ministers' approach to this particular right to buy, which will be important for community bodies to consider in relation to future applications. ${ }^{7}$ Further, two competing models of landownership are thrown into sharp relief in the application; one which considers the land as purely a financial investment and the other which has a more holistic appreciation of the value of the land to the local community.

\section{A. ELIGIBLE LAND}

The first ground on which the Scottish Ministers rejected HCWG's application was that the land was not eligible land in terms of section 97C of the 2003 Act. As the right to buy abandoned, neglected or detrimental land is targeted towards poorly managed land, there are several criteria as to what is "eligible land". HCWG claimed the land in question was wholly or mainly abandoned or neglected, rather than detrimental. ${ }^{8}$ For this category of eligible land, the Scottish Ministers must have regard to matters relating to the physical condition of the land, the designation or classification of the land, and the use or management of the land, which are set out in secondary legislation. ${ }^{9}$

There were three main issues raised by HCWG: safety concerns, the invasion of non-native species and fly-tipping. According to $\mathrm{HCWG}$, the owners had prevented public access to the land since 2007 and there was evidence that the owners claimed the land was treacherous underfoot and hazardous, opposing any attempt by the Local Authority to allow public access under Part 1 of the 2003 Act. There used to be a mature woodland on the site but in 2011 the owners cleared the site of trees, in breach of the Tree Preservation Order. The owners then refused to implement a Tree Replacement Notice $^{10}$ and the Local Authority had to replant trees

\footnotetext{
${ }^{6}$ See Register of Applications by Community Bodies to Buy Land at https://roacbl.ros.gov.uk/index.html.

${ }^{7}$ While decision letters are not to be analysed as legislation or judgments, they do indicate the way in which ministerial discretion is being exercised in relation to the right to buy. 8 "Abandoned or neglected land" is one category of eligible land, and "detrimental land" is the other, Land Reform (Scotland) Act 2003 s 97C(2).

${ }^{9}$ Community Right to Buy (Abandoned, Neglected or Detrimental Land) (Eligible Land, Regulators and Restrictions on Transfers and Dealing) (Scotland) Regulations 2018, SSI 2018/201 regs 2-5 (“2018 Regulations").

${ }^{10}$ Tree Replacement Notice 11/00107/ENOTH2, dated 12 February 2013. These notices can be issued by planning authorities under s 168 of the Town and Country Planning (Scotland) Act 1997.
} 
on the site. There were invasive non-native species on the land including Himalayan Balsam, which HCWG argued were colonising the land and evidence of abandonment and neglect. Finally, garden waste was often dumped on the land and the owners had not done anything to prevent this. Overall, the assessment of HCWG was that the land was not being actively used, and instead was "held speculatively by the current owners...in the hope that they will eventually succeed in overcoming longstanding Council planning policy, which designates the land as an Open Space Protection Area". ${ }^{11}$

The arguments by HCWG in relation to the status of the land made reference to a broad range of sources including historic Ordnance Survey maps showing the presence of woodland on the site, the Scottish Government's Land Rights and Responsibilities Statement, ${ }^{12}$ the Scottish Invasive Species Initiative led by Scottish Natural Heritage ${ }^{13}$ and a report on the condition of the site by an arboricultural and environmental consultant. However, the application did not systematically go through the relevant provisions in the legislation and relate their arguments specifically to these provisions. This was the reason behind the comment by the Scottish Ministers that while "there is no requirement that a case should be made for every Regulation, it would be expected a strong case is made with the Regulations in mind". ${ }^{14}$ For future applications, community bodies should therefore pay close attention to the various complex provisions and frame their application in this context.

The Scottish Ministers dealt with the arguments of HCWG in detail with specific reference to the matters referred to in the legislation. They were not convinced the land presented a risk to public safety. ${ }^{15}$ The Ministers also did not consider there was strong evidence that the physical condition of the land caused, or was likely to cause, environmental harm, within the meaning of section 17(2) of the Regulatory Reform (Scotland) Act 2014. ${ }^{16}$ Though the land was accepted to be designated as an Open Space Protection Area and protected by a Tree

\footnotetext{
${ }^{11}$ Helensburgh Application, Response to Question 5.2, Appendix 24.

${ }^{12}$ Scottish Government, Land Rights and Responsibilities Statement (2017).

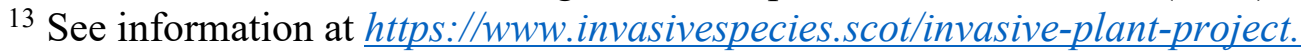

${ }^{14}$ Helensburgh Decision, 11.

${ }^{15}$ Helensburgh Decision, 10. That the land is a "risk to public safety" is a matter related to the physical condition of the land, 2018 Regulations reg 3(1)(c)(i).

${ }^{16}$ Helensburgh Decision, 10-11. This is again a matter related to the physical condition of the land, 2018 Regulations reg 3(1)(c)(iii). "Environmental harm" within s 17(2) of the Regulatory Reform (Scotland) Act 2014 means "harm to the health of human beings or other living organisms"; "harm to the quality of the environment"; "offence to the senses of human beings"; "damage to property"; or "impairment of, or interference with, amenities or other legitimate uses of the environment".
} 
Preservation Order, these were not relevant considerations in relation to this application, as the land was maintaining its designation.

Nevertheless, the seemingly most relevant issue for the decision in relation to eligible land was that HCWG did not contact the owners to try to resolve the issues relating to invasive nonnative species and fly-tipping before making the application. The owners have now contacted the police regarding the tipping and indicated that they are willing to work with HCWG to put in place a land management scheme for the land. Due to these actions, the Scottish Ministers determined that the land could not be classed as wholly or mainly neglected or abandoned, despite the evidence provided by HCWG of the treatment of the land over the last 16 years. ${ }^{17}$ This confirms the possibility, which had been raised previously, that applications under this right to buy could be blocked by basic maintenance being undertaken at the last minute, though merely contacting the police and agreeing to enter into a land management scheme is a low bar indeed. ${ }^{18}$ Contacting the owners to try to resolve issues relating to the land prior to submitting an application is not a requirement of the legislation. ${ }^{19}$ If, however, the owners do indeed proactively work with the community to manage the land, and this results in benefits for the community, this could be seen as a positive outcome of the legislation and the realisation of the Scottish Government's policies for community engagement in relation to land..$^{20}$

\section{B. PUBLIC INTEREST}

The second ground on which HCWG's application was rejected was that the Scottish Ministers were not satisfied that the exercise of the right to buy was in the public interest. ${ }^{21}$ In their application, HCWG outlined the range of benefits that their plans would bring within three

\footnotetext{
${ }^{17}$ Helensburgh Decision, 10.

$18 \mathrm{~J}$ A Lovett (n 5), 201 and R McMorran et al, Review of the effectiveness of current community mechanisms and of options for supporting the expansion of community ownership in Scotland (Scottish Land Commission, Commissioned Report) (2018) section 4.4 .

${ }^{19}$ In relation to detrimental land, there is a requirement to contact the relevant regulators and request them to take action before submitting an application, Land Reform (Scotland) Act $2003 \mathrm{~s} 97 \mathrm{H}(5)(\mathrm{b})$. For both categories of eligible land, the community body must have tried and failed to buy the land, Land Reform (Scotland) Act 2003 s 97H(1)(j). This latter requirement had been met in this application, Helensburgh Decision, 28.

${ }^{20}$ See Scottish Government, Guidance on Engaging Communities in Decisions Relating to Land (2018) and Scottish Government, Land Rights and Responsibilities Statement (2017) Principle 6.

${ }^{21}$ Land Reform (Scotland) Act 2003 s 97H(1)(b)(i).
} 
categories: environmental and amenity; social, educational and health; and economic. ${ }^{22} \mathrm{HCWG}$ planned to regenerate the woodland and create accessible pathways for use by the local community. They would encourage local schools to use the land for environmental education and allow local people to use the woods to develop skills in woodland management. HCWG referred to the Scottish Government's National Performance Framework ${ }^{23}$ and related their plans to the National Outcomes for Communities, Economy, Environment, Health and Human Rights. ${ }^{24}$ In response, the owners argued that HCWG was using the right to buy to prevent development, which was contrary to the Scottish Government's guidance on the legislation. ${ }^{25}$

The Scottish Ministers reaffirmed that this right to buy is not intended to be used to block development. This has also been noted in relation to the pre-emptive right to buy in Part 2 of the 2003 Act. ${ }^{26}$ However, this was not a material factor in the Scottish Ministers' decision because due to its existing designation, the land was not available for housing development. ${ }^{27}$ A more important issue was that there was insufficient evidence of the need of the community which would be satisfied by the exercise of this right to buy. The Scottish Ministers stated:

As this is a compulsory purchase Ministers would expect a strong case to be made by a community body showing that the [sic] were no suitable alternatives available for the community body to realise its aims and that there are no other areas in Helensburgh that could be used by the community for the same purposes. ${ }^{28}$

Demonstrating community need in relation to the pre-emptive right to buy was discussed in Coastal Regeneration Alliance Ltd v Scottish Ministers,${ }^{29}$ in which Sheriff Ross found that reference to community need by the Scottish Ministers when discussing public interest was not proof of an additional requirement, but merely an explanation of how the statutory tests had

22 This structure reflects the three pillars of sustainability, on which see B Purvis et al "Three pillars of sustainability: in search of conceptual origins" (2019) 14 Sustainability Science 681.

${ }^{23}$ See information here https://nationalperformance.gov.scot.

${ }^{24}$ Helensburgh Application, Response to Question 9.1, Appendix 36-39.

${ }^{25}$ See Scottish Government, "Community Right to Buy Abandoned, Neglected or Detrimental Land: Guidance for Applications" (October 2018), 2.

${ }^{26}$ See Holmehill Ltd $v$ The Scottish Ministers 2006 SLT (Sh Ct) 79 and discussion of this case in M M Combe, "No place like Holme: Community Expectations and the Right to Buy" (2007) 11 Edin LR 109. Caution should be exercised in relation to this decision and the commentary as relevant provisions of the Land Reform (Scotland) Act 2003 have since been amended.

27 Though it was noted that these designations can change.

${ }^{28}$ Helensburgh Decision, 16.

29 [2016] SC EDIN 60. Again, relevant provisions of the 2003 Act have been amended since this decision. 
been applied. ${ }^{30}$ Nevertheless, understanding how the Scottish Ministers have exercised their discretion in the past is crucial for community bodies seeking to achieve future successful applications. Showing a community need which can only be met through transfer of the land in question, especially when the land will be by definition in a poor state, is a substantial hurdle for community bodies to surpass.

\section{FURTHERING THE ACHIEVEMENT OF SUSTAINABLE DEVELOPMENT}

In relation to abandoned or neglected land, there are two tests connected to sustainable development which a community body has to meet: firstly, that exercise by the community body of the right to buy is compatible with furthering the achievement of sustainable development in relation to the land, and secondly, that the achievement of sustainable development in relation to the land would be unlikely to be furthered by the owner of the land continuing to be its owner. ${ }^{31} \mathrm{HCWG}$ 's application did not meet either of these tests. In the application, HCWG referred to, inter alia, the UK's Shared Framework for Sustainable Development $^{32}$ as well as the United Nations' Global Goals for Sustainable Development, ${ }^{33}$ and related their plans to five of these Goals: Ensure healthy lives and promote well-being for all at all ages; Quality education; Make cities inclusive, safe, resilient and sustainable; Take urgent action to combat climate change its impacts; and Life on land. ${ }^{34}$

However, the Ministers were concerned that there was no income generation aspect to the application and the plans relied entirely on grants and volunteers. In other words, there was no financial sustainability shown. It was stated that whilst: "it is not a requirement under the Act, Ministers would expect, when considering a case for compulsory purchase, that the community body would have detailed financial costings in order to help determine whether the project is financially viable." 35 Funding has been highlighted as a persistent problem for communities seeking to exercise the rights to buy and again, as this right to buy is targeted towards poorly managed land, the community may face high costs in terms of remediation and

\footnotetext{
${ }^{30}$ Ibid at para 61.

${ }^{31}$ Land Reform (Scotland) Act 2003 s 97H(1)(b)(ii) and (c).

${ }^{32}$ Department for Environment, Food and Rural Affairs, One future - different paths: the UK's shared framework for sustainable development (2005).

${ }^{33}$ UN General Assembly, Transforming our world: the 2030 Agenda for Sustainable Development (2015).

${ }^{34}$ Helensburgh Application, Response to Question 8.2, Appendix 28-32.

${ }^{35}$ Helensburgh Decision, 21.
} 
ongoing management. ${ }^{36}$ Creating a viable business plan may also be beyond the expertise of the community. However, technical assistance funding is available from the Scottish Land Fund to prepare business plans. ${ }^{37}$ Once more, this an issue to be noted, and addressed, by community bodies seeking to exercise this right to buy in the future.

Further, the Scottish Ministers stated that as the owners had shown a willingness to engage with the community regarding the management of the land there was the possibility for the current owners to achieve a sustainable future for the land. ${ }^{38}$ Nevertheless, there was a distinct warning given to the owners, that the application had the potential to meet the sustainable development criteria, and if cooperation between the owners and HCWG was unsuccessful, HCWG could re-apply to exercise this right to buy in the future. ${ }^{39}$ This certainly will provide an incentive for community engagement.

\section{CONCLUSION}

Taking a step back from the detail of the application and the decision of the Scottish Ministers, the contrast between the two competing visions of ownership involved is vivid. HCWG engaged with the history of the land, and sought to restore native ecosystems as well as enhance the health, education and skills of local people. This is a holistic appreciation of the land, which sees its value and potential for both human and non-human communities. Conversely, the owners' treatment of the land and responses to the application revealed that they saw the land as a fungible asset, which just needed the grant of planning permission to enhance its financial value. ${ }^{40}$ However, the breadth of sources which HCWG referred to in order to support their application shows that their holistic vision of ownership is scaffolded by a range of national and international policies. The Scottish Ministers were also clear that although this particular application was refused, future applications in relation to the land may not be, if community engagement and sustainable development were not pursued by the owners. Therefore, although

\footnotetext{
${ }^{36} \mathrm{R}$ McMorran et al, Review of the effectiveness of current community mechanisms (n 18), section 8.2.1.

${ }^{37}$ See Scottish Land Fund, Guidance Notes, 5. Available at https://www.tnlcommunityfund.org.uk/media/documents/scottish-land-fund/Scottish-LandFund-Guide.pdf? mtime $=20190906142702 \&$ focal $=$ none.

${ }^{38}$ Helensburgh Decision, 25.

${ }^{39}$ Helensburgh Decision, 25. A similar comment is made at 9 when discussing eligible land. HCWG also have a pre-emptive right to buy registered over the land, under Land Reform (Scotland) Act 2003 part 2, registration number CB00204.

40 The contrast between these visions is reminiscent of the dichotomy explored in E Peñalver, "Land Virtues" (2008-2009) 94 Cornell LR 821.
} 
the challenges facing communities in exercising this right to buy are significant, there is increasing momentum towards a holistic and sustainable vision of land ownership, which can no longer be ignored.

Jill Robbie

University of Glasgow 